\title{
Hourly Simulation of Parabolic Trough Solar Collector with Simultaneous Solar Radiation and Weather Conditions during Sunshine Period in Cairo-Egypt
}

\author{
Ashraf Kotb \\ Department of Mechanical Power Engineering \\ Faculty of Engineering - Ain Shams University - Cairo - Egypt
}

\begin{abstract}
The present work is an attempt to simulate the single-pass parabolic trough collector from thermal and optical point of view, considering the simultaneous hourly profiles of solar radiation, ambient dry-bulb temperature, and wind speed during the sunshine period for specific geographical location. Also, computer program is constructed and presented as simulator to predict the performance of the parabolic trough collector with varying operating, design, and weather conditions. For the studied case, the results are; the maximum reflected solar radiation from the mirror surface is $20849.0 \mathrm{~W} / \mathrm{m}^{2}$ at hour 12 and distributed as; $65.8 \%$ and 1.53 $\%$ absorbed by the absorber, cover tubes respectively while $32.67 \%$ is dissipated as heat loss to the surrounding environment. For $0.001 \mathrm{~kg} / \mathrm{s}$ of heat transfer fluid, results showed that; the temperature of the absorber tube is $597.0^{\circ} \mathrm{C}$ at hour 12 , while the heat transfer fluid is $539.0^{\circ} \mathrm{C}$ at hour 13.30 and the cover tube is $258.6{ }^{\circ} \mathrm{C}$ at hour 11.097. It is noted that; after hour 14.317 and beyond the heat transfer from the absorber tube to the heat transfer fluid reverses its direction, while at the sunshine end, the temperatures are $342.0{ }^{\circ} \mathrm{C}$ for heat transfer fluid, 204.0 ${ }^{\circ} \mathrm{C}$ for the absorber tube, and $50.2{ }^{\circ} \mathrm{C}$ for the cover tube at the exit section.
\end{abstract}

Key Words: Solar Parabolic Trough Simulation Cairo Egypt

\section{Nomenclature}

A accommodation coefficient

$\mathrm{A}_{1}$ cross sectional flow area for absorber tube

$\mathrm{A}_{\mathrm{a}} \quad$ cross sectional area for absorber tube thickness $\mathrm{A}_{\mathrm{c}} \quad \begin{aligned} & \text { cross sectional area for cover } \\ & \text { tube thickness }\end{aligned}$

$\mathrm{C}_{\mathrm{a}}$ specific heat for absorber

$\mathrm{C}_{\mathrm{a}} \quad$ material

$\mathrm{C}_{\mathrm{c}} \quad$ specific heat for cover material

$\mathrm{C}_{\mathrm{f}} \quad$ specific heat for heat transfer fluid

$\mathrm{d}_{1} \quad$ absorber tube inner diameter

$\mathrm{d}_{2} \quad$ absorber tube outer diameter

$\mathrm{d}_{3} \quad$ cover tube inner diameter

$\mathrm{d}_{4} \quad$ cover tube outer diameter

$\mathrm{d}_{\mathrm{g}}$ characteristics length for $\mathrm{d}_{\mathrm{mol}} \begin{aligned} & \text { molecular diameter for annuals } \\ & \text { gas }\end{aligned}$

f internal friction factor for absorber tube

$\mathrm{F}_{\mathrm{ac}} \quad$ view factor between absorber and cover tubes

g gravitational acceleration

H rate of total enthalpy for the W H $\mathrm{m} / \mathrm{s}^{2}$

\begin{tabular}{|c|c|c|c|}
\hline $\begin{array}{l}\mathrm{m}^{2} \\
\mathrm{~m}^{2}\end{array}$ & $\mathrm{~h}_{1}$ & $\begin{array}{l}\text { convective heat transfer } \\
\text { coefficient between absorber } \\
\text { inner surface and heat transfer } \\
\text { fluid }\end{array}$ & $\mathrm{W} / \mathrm{m}^{2} \mathrm{~K}$ \\
\hline /kg.K & $\mathrm{h}_{2}$ & $\begin{array}{l}\text { convective heat transfer } \\
\text { coefficient between absorber } \\
\text { outer surface and cover inner } \\
\text { surface }\end{array}$ & $\mathrm{W} / \mathrm{m}^{2} \mathrm{~K}$ \\
\hline$/ \mathrm{kg} . \mathrm{K}$ & $\mathrm{h}_{3}$ & 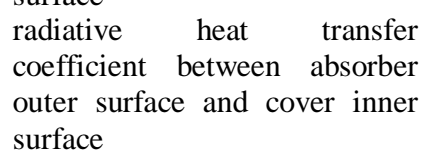 & $\mathrm{W} / \mathrm{m}^{2} \mathrm{~K}$ \\
\hline $\mathrm{m}$ & $\mathrm{h}_{4}$ & $\begin{array}{l}\text { convective heat transfer } \\
\text { coefficient between cover outer } \\
\text { surface and ambient }\end{array}$ & $\mathrm{W} / \mathrm{m}^{2} \mathrm{~K}$ \\
\hline $\mathrm{m}$ & $\mathrm{h}_{5}$ & $\begin{array}{l}\text { radiative heat transfer } \\
\text { coefficient between cover outer } \\
\text { surface and sky }\end{array}$ & $\mathrm{W} / \mathrm{m}^{2} \mathrm{~K}$ \\
\hline $\mathrm{m}$ & $\begin{array}{l}\mathrm{IC}_{\mathrm{mol}} \\
\mathrm{K}\end{array}$ & interaction coefficient & \\
\hline $\mathrm{cm}$ & $\begin{array}{l}\mathrm{L} \\
\dot{\mathrm{m}}_{\mathrm{f}}\end{array}$ & $\begin{array}{l}\text { Absorber length } \\
\text { rate of mass flow through } \\
\text { absorber tube }\end{array}$ & $\underset{\mathrm{mg} / \mathrm{s}}{\mathrm{m}}$ \\
\hline & $\mathrm{Nu}_{\mathrm{f}}$ & $\begin{array}{l}\text { Nusselt number for heat transfer } \\
\text { fluid }\end{array}$ & - \\
\hline & $\mathrm{P}$ & Pressure of annuals gas & \\
\hline $\mathrm{m} / \mathrm{s}^{2}$ & $\operatorname{Pr}_{\infty}$ & Prandtl number for ambient air & - \\
\hline W & $\operatorname{Pr}_{f}$ & $\begin{array}{l}\text { Prandtl number for heat transfer } \\
\text { fluid }\end{array}$ & - \\
\hline & $\operatorname{Pr}_{\mathrm{f}_{\mathrm{a}}}$ & $\begin{array}{l}\text { Prandtl number for heat transfer } \\
\text { fluid at absorber temperature }\end{array}$ & - \\
\hline
\end{tabular}




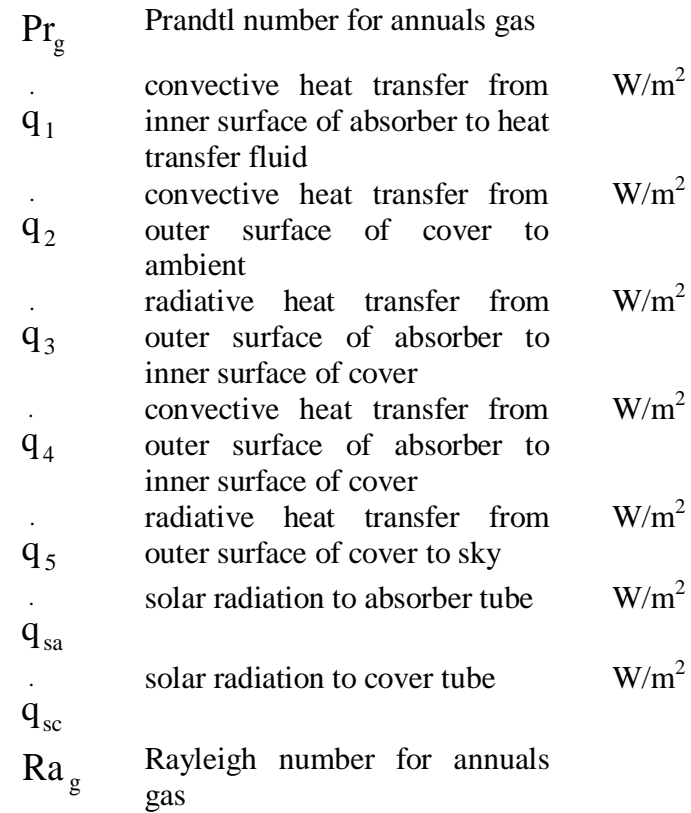

\begin{tabular}{|c|c|}
\hline $\operatorname{Re}_{\infty}$ & $\begin{array}{l}\text { Reynolds number for ambient } \\
\text { air }\end{array}$ \\
\hline $\operatorname{Re}_{\mathrm{f}}$ & $\begin{array}{l}\text { Reynolds number for heat } \\
\text { transfer fluid }\end{array}$ \\
\hline $\mathrm{T}_{\infty}$ & temperature of ambient \\
\hline $\mathrm{T}_{\mathrm{a}}$ & temperature of cover tube \\
\hline $\mathrm{T}_{\mathrm{c}}$ & temperature of absorber tube \\
\hline $\mathrm{T}_{\mathrm{f}}$ & $\begin{array}{l}\text { temperature of heat transfer } \\
\text { fluid }\end{array}$ \\
\hline $\mathrm{T}_{\mathrm{f}}$ & $\begin{array}{l}\text { temperature of external film } \\
\text { boundary layer }\end{array}$ \\
\hline$\overline{\mathrm{T}}_{\mathrm{g}}$ & temperature of annuals gas \\
\hline $\mathrm{T}_{\text {sky }}$ & temperature of sky \\
\hline $\mathrm{t}$ & time \\
\hline $\mathrm{U}_{\mathrm{f}}$ & $\begin{array}{l}\text { internal energy for control } \\
\text { volume from heat transfer fluid }\end{array}$ \\
\hline $\mathrm{U}_{\mathrm{a}}$ & $\begin{array}{l}\text { internal energy for control } \\
\text { volume from absorber tube }\end{array}$ \\
\hline $\mathrm{U}_{\mathrm{c}}$ & $\begin{array}{l}\text { internal energy for control } \\
\text { volume from cover tube }\end{array}$ \\
\hline $\mathrm{Z}_{\mathrm{mol}}$ & $\begin{array}{l}\text { Mean free path between } \\
\text { collisions of a molecule of } \\
\text { annuals gas }\end{array}$ \\
\hline W & Collector Width \\
\hline
\end{tabular}

\section{Greek Symbols}

$\rho_{\mathrm{f}} \quad$ density of heat transfer fluid

$\mathrm{kg} / \mathrm{m}^{3}$

$\rho_{\mathrm{a}} \quad$ density of absorber material

$\mathrm{kg} / \mathrm{m}^{3}$

$\mathrm{kg} / \mathrm{m}^{3}$

$\rho_{c} \quad$ density of cover material

$\rho_{\mathrm{cm}} \quad$ Clean mirror reflectance

$\rho_{\infty} \quad$ density for ambient air

$\mathrm{kg} / \mathrm{m}^{3}$

$\mu_{\infty} \quad$ Dynamic viscosity for ambient

$\mu_{\mathrm{f}} \quad$ dynamic viscosity for heat

$\lambda_{\mathrm{f}} \quad$ thermal conductivity for heat

$\mathrm{W} / \mathrm{m} . \mathrm{K}$

$\lambda_{\infty} \quad$ thermal conductivity for $\quad \mathrm{W} / \mathrm{m} . \mathrm{K}$

$\mathrm{m} / \mathrm{s}$

$\mathrm{v}_{\infty} \quad$ speed for ambient air

$\lambda_{\text {mol }}$ thermal conductance of annuals gas

$\gamma \quad$ specific heat ratio of annuals gas

$\beta_{g} \quad$ coefficient of volumetric thermal expansion of annuals gas

$\beta_{\infty} \quad$ coefficient of volumetric thermal expansion for ambient air

$\mathrm{W} / \mathrm{m} . \mathrm{K}$

$\mathrm{K}^{-1}$

$\mathrm{W} / \mathrm{m}^{2} \mathrm{k}^{-4}$

$\begin{array}{ll}\alpha_{\infty} & \text { thermal diffusivity for } \\ \alpha_{\mathrm{a}} & \text { air } \\ \alpha_{\mathrm{c}} & \text { Absorber absorptance } \\ \tau_{\mathrm{c}} & \text { Cover absorptance }\end{array}$

$\tau_{\mathrm{c}} \quad$ Cover transmittance

$v_{\infty} \quad$ kinematic viscosity for annuals gas

$\lambda_{\mathrm{g}}$ thermal conductivity for annuals $\mathrm{m}^{2} / \mathrm{s}$ $\mathrm{m}^{2} / \mathrm{s}$ gas

$\varepsilon_{\mathrm{c}} \quad$ emissivity of cover tube

$\sigma \quad$ Stephan-Boltzmann constant

$\mathrm{Ra}_{\infty} \quad$ Rayleigh number for ambient

$\alpha_{g} \quad$ thermal diffusivity for annuals

$\mathrm{m}^{2} / \mathrm{s}$
$\mathrm{m}^{2} / \mathrm{s}$ emissivity of absorber tube

$\varepsilon_{\mathrm{a}}$

Shadowing term

$\varepsilon_{2}$

Tracking error term

$\varepsilon_{3} \quad$ Mirror alignment error

$\varepsilon_{4} \quad$ Dirt on mirrors

$\varepsilon_{5} \quad$ Dirt on cover

$\varepsilon_{6} \quad$ Unaccounted term

$\eta_{\mathrm{c}} \quad$ Cover effective optical

efficiency

$\eta_{\mathrm{a}} \quad$ Absorber optical efficiency

$v_{\mathrm{g}} \quad \begin{aligned} & \text { kinematic viscosity for ambient } \\ & \text { air }\end{aligned}$ 


\section{INTRODUCTION}

The first practical experience with parabolic trough collectors goes back to 1870, when a successful engineer, John Ericsson, a Swedish immigrant to the United States, designed and built a $3.25 \mathrm{~m}^{2}$ aperture collector which drove a small $373.0 \mathrm{~W}$ engine, with steam was produced directly inside the solar collector (today called Direct Steam Generation-DSG).

There are many different ways that solar energy can be applied, but there are also many different methods for collecting the solar energy from incident radiation. The more popular types of solar collectors are;

- Glazed flat-plate solar collectors

- Unglazed flat-plate solar collectors

- Unglazed perforated plate collectors

- Back-pass solar collectors

- Concentrating solar collectors

- Air based solar collectors

- Batch solar collectors

- Solar cookers

- Liquid-based solar collectors

- Parabolic dish systems

- Parabolic trough systems

- Power tower systems

- Stationary concentrating solar collectors

- Vacuum tube solar collectors

Concentrating solar collectors operate by using reflectors to concentrate sunlight on the absorber of a solar collector, the size of the absorber can be dramatically reduced, which reduces heat losses and increases efficiency at high temperatures. Another advantage is that reflectors can cost substantially less per unit area than collectors. This class of collector is used for high-temperature applications such as steam production for the generation of electricity and thermal detoxification. Stationary concentrating collectors may be liquid-based, airbased, or even an oven such as a solar cooker. There are four basic types of concentrating collectors:

- Parabolic trough

- Parabolic dish

- Power tower

- Stationary concentrating collectors

In Egypt, the first power station utilize solar energy is Al Kuraymat electrical power station with capacity of 120.0 MW from fossil fuel and 20.0 MW from solar energy by using parabolic trough collectors. A parabolic trough collector system as illustrated in Fig. 1 is composed of a sheet of reflective material, usually silvered acrylic, which is bent into a parabolic shape. Many such sheets are put together in series to form long troughs. These modules are supported from the ground by simple pedestals at both ends. The long parabolic shaped modules have a linear focus (focal line) along which an absorber is mounted. The absorber is generally a black metal pipe which contains a fluid that is heated to a high temperature by the energy of the sunlight; the hot fluid is piped to equipment. The absorber encased in a glass pipe to limit heat loss by convection. The metal tube's surface is often covered with a selective coating that features high solar absorbance and low thermal emittance. The glass tube itself is typically coated with antireflective coating to enhance transmissivity. A vacuum or air can be applied in the space between the glass and the metal pipes to further minimize heat loss and thus boost the system's efficiency. The parabolic trough is usually aligned on a north-south axis, and rotated to track the sun as it moves across the sky each day. Alternatively, the trough can be aligned on an east-west axis; this reduces the overall efficiency of the collector due to cosine loss but only requires the trough to be aligned with the change in seasons, avoiding the need for tracking motors. This tracking method works correctly at the spring and fall equinoxes with errors in the focusing of the light at other times during the year (the magnitude of this error varies throughout the day, taking a minimum value at solar noon). 
There is also an error introduced due to the daily motion of the sun across the sky, this error also reaches a minimum at solar noon. Due to these sources of error, seasonally adjusted parabolic troughs are generally designed with a lower solar concentration ratio. The heat transfer fluid flows through the absorber, collecting and transporting thermal energy. The HTF in PTC systems is usually water or oil, where oil is generally preferred due to its higher boiling point and relatively low volatility.

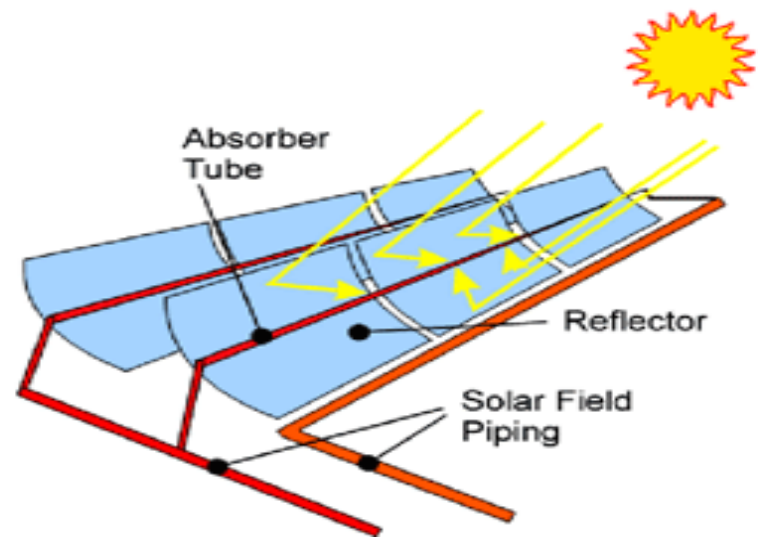

Fig. 1: Parabolic Trough Collector System

The parabolic trough collector's performance is highly sensitive to the weather conditions such as ambient dry-bulb temperature and wind speed in addition to the solar radiation. It is noticed that; during the mathematical modeling and simulation of parabolic trough collectors and other solar systems, the researchers do not take into account the hourly profile of solar radiation, ambient dry-bulb temperature, and wind speed simultaneously. Mattew et. al. [14] studied by numerical analysis the heat loss from the absorber tube, while the ambient dry-bulb temperature was kept constant at $25{ }^{\circ} \mathrm{C}$ and neglecting the wind speed. Arpakon et. al. [2] studied the distribution of velocity and temperature of flowing water in a solar parabolic trough receiver with no mention the mathematical treatment of ambient temperature and wind speed. A. Giostri et. al. [1] compared two linear collectors in solar thermal plant; parabolic trough vs. Fresnel with ambient temperature was kept constant at $19.8{ }^{\circ} \mathrm{C}$ with negligible wind speed. García et. al. [7] studied by numerical simulation the parabolic trough solar collector using counter flow concentric circular heat exchangers, where for each studied case; the solar radiation, the ambient temperature, and wind speed were kept constant for each case. Ming et. al. [15] presented performance model for a linear parabolic trough solar collector with ambient temperature kept constant at $20{ }^{\circ} \mathrm{C}$ with constant wind speed of $4 \mathrm{~m} / \mathrm{s}$. M. Ouagued et. al. [12] simulated the temperature and heat gain by solar parabolic trough collector in Algeria considering constant solar radiation, ambient dry-bulb temperature, and wind speed. The work presented herein, is an attempt to simulate the single-pass parabolic trough collector from thermal and optical point of view, considering the simultaneous hourly profiles of solar radiation, ambient drybulb temperature, and wind speed during the sunshine period for specific location. Also, computer program is constructed and presented as simulator to predict the performance of the parabolic trough collector with varying operating, design, and weather conditions.

\section{SIMULATION OF PARABOLIC TROUGH SOLAR COLLECTOR (PTC)}

Fig. 2, illustrates a control volume from a parabolic trough collector, the control volume contains three components; cover tube, absorber tube, and fluid. The incoming solar radiation reaches the cover tube is divided into three values; reflected value to the surrounding, absorbed value that is responsible for the cover tube temperature rise, and transmitted value that reaches the absorber tube. Also, the cover tube radiates heat to the surrounding and convects heat to the ambient, while the cover tube receives radiation and convection heat through the annuals gas from the absorber tube.

The transmitted value from the incoming solar radiation from the cover tube is responsible for the temperature rise of the absorber tube, where in addition to the radiative and convective heats to the cover tube it also transfers heat to the heat transfer fluid by convection. 


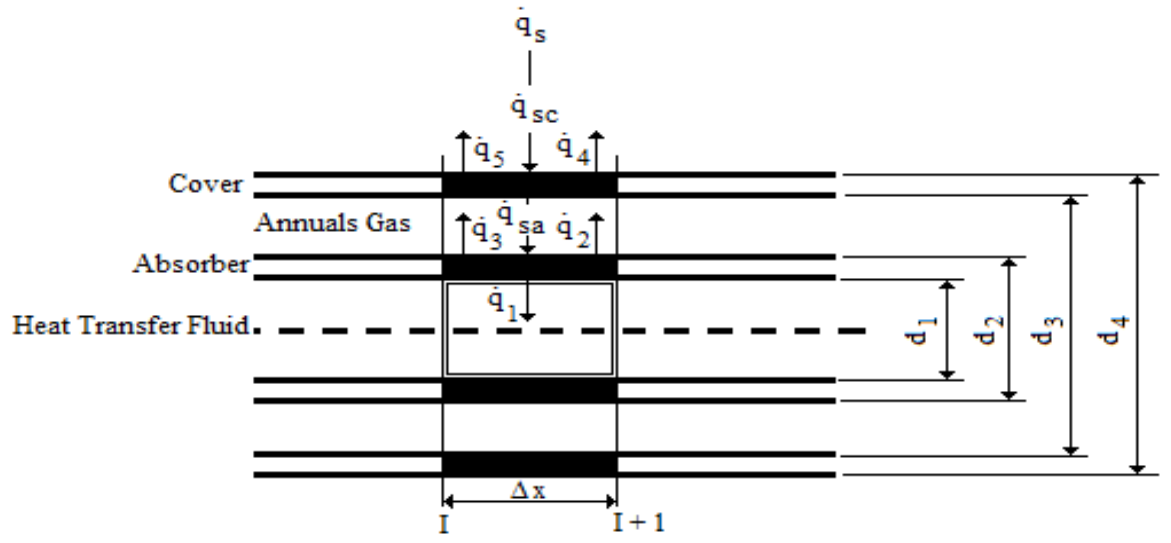

Fig. 2: Control Volume from Parabolic Trough Solar Collector

The present work concerns the transient, one-dimensional thermal behavior of the parabolic trough solar collector and is based on the following assumptions:

1. The thermophysical properties for the cover tube and absorber tube materials are independent on the temperature.

2. The variations in both kinetic and potential energies for the heat transfer fluid are negligible.

3. Conductive heat transfers in the axial and radial directions for the absorber and cover tubes are negligible.

\subsection{Simulation of Solar Radiation}

For the parabolic trough solar collector with certain dimensions and geometry, the solar radiation concentrated and reflected from the parabolic mirror surface is determined by:

$\mathrm{q}_{\mathrm{s}}=\mathrm{CI} \rho_{\text {mirror }}$

Where, $\mathrm{C}$ is defined as the concentration ratio and defined by:

$\mathrm{C}=\frac{\mathrm{W}-\mathrm{d}_{2}}{\pi \mathrm{d}_{2}}$

The solar radiation absorbed by the cover tube is determined by:

$\mathrm{q}_{\mathrm{sc}}=\mathrm{q}_{\mathrm{s}} \eta_{\mathrm{c}} \alpha_{\mathrm{c}}$

$\eta_{\mathrm{c}}=\varepsilon_{1} \varepsilon_{2} \varepsilon_{3} \varepsilon_{4} \varepsilon_{5} \varepsilon_{6} \rho_{\mathrm{c}} \mathrm{K}$

$\mathrm{K}=\operatorname{COS} \theta+0.000884 \theta-0.00005369 \theta^{2}$

The solar radiation absorbed by the absorber tube is determined by:

$\dot{\mathrm{q}}_{\mathrm{sa}}=\mathrm{q}_{\mathrm{s}} \eta_{\mathrm{a}} \alpha_{\mathrm{a}}$

$\eta_{\mathrm{a}}=\eta_{\mathrm{c}} \tau_{c}$

\subsection{Simulation of Heat Transfer Fluid}

The heat transfer fluid flows inside the absorber tube is simulated by the conservation of energy rate for finite control volume under unsteady-state, steady flow conditions. The control volume undergoes convective heat transfer from the inner surface of the absorber tube, inflow, and outflow enthalpies. The conservation of energy yields to Eq. 8;

$\frac{\mathrm{dU}_{\mathrm{f}}}{\mathrm{dt}}=\dot{\mathrm{q}}_{1} \pi \mathrm{d}_{1} \mathrm{dx}-\frac{\mathrm{d}}{\mathrm{dx}} \dot{\mathrm{H}}_{\mathrm{x}} \mathrm{dx}$

Where;

$\mathrm{U}_{\mathrm{f}}=\rho_{\mathrm{f}} \mathrm{A}_{1} \mathrm{~T}_{\mathrm{f}} \mathrm{dx}$ 


$$
\begin{aligned}
& \dot{\mathrm{q}}_{\mathrm{l}}=\mathrm{h}_{1}\left(\mathrm{~T}_{\mathrm{a}}-\mathrm{T}_{\mathrm{f}}\right) \\
& \dot{\mathrm{H}}_{\mathrm{x}}=\dot{\mathrm{m}}_{\mathrm{f}} \mathrm{C}_{\mathrm{f}} \mathrm{T}_{\mathrm{f}}
\end{aligned}
$$

Therefore Eq. 8 is re-written to be Eq. 12, which represents the one-dimensional, time distribution for the temperature of the heat transfer fluid.

$$
\frac{\mathrm{dT}_{\mathrm{f}}}{\mathrm{dt}}=\frac{1}{\rho_{\mathrm{f}} \mathrm{A}_{1} \mathrm{C}_{\mathrm{f}}}\left(\dot{\mathrm{q}}_{1} \pi \mathrm{d}_{1}-\dot{\mathrm{m}}_{\mathrm{f}} \mathrm{C}_{\mathrm{f}} \frac{\mathrm{dT}_{\mathrm{f}}}{\mathrm{dx}}\right)
$$

Solution of Eq. 12 requires the value of convective heat transfer coefficient between the inner surface of the absorber tube and the heat transfer fluid, which is determined according its flow regime as:

$$
\operatorname{Re}_{\mathrm{f}}=\frac{4 \mathrm{~m}_{\mathrm{f}}}{\pi \mathrm{d}_{1} \mu_{\mathrm{f}}}
$$

For the fully developed laminar flow regime [9]:

$$
\operatorname{Re}_{\mathrm{f}}<2300 \quad \mathrm{Nu}_{\mathrm{f}}=4.36
$$

For transitional and turbulent flow regime [8]:

$$
2300 \leq \operatorname{Re}_{\mathrm{f}} \leq 5 \times 10^{6} \mathrm{Nu}_{\mathrm{f}}=\frac{\left(\frac{\mathrm{f}}{8}\right)\left(\operatorname{Re}_{\mathrm{f}}-1000\right) \operatorname{Pr}_{\mathrm{f}}}{1+1.27 \sqrt{\frac{\mathrm{f}}{8}}\left(\operatorname{Pr}_{\mathrm{f}}^{\frac{2}{3}}-1\right)}\left(\frac{\operatorname{Pr}_{\mathrm{f}}}{\operatorname{Pr}_{\mathrm{fa}}}\right)^{0.11}
$$

Where;

$$
\begin{aligned}
& \mathrm{f}=\left(1.82 \ln \mathrm{Re}_{\mathrm{f}}-1.64\right)^{-2} \\
& \mathrm{~h}_{1}=\frac{\mathrm{Nu}_{\mathrm{f}} \lambda_{\mathrm{f}}}{\mathrm{d}_{1}}
\end{aligned}
$$

\subsection{Simulation of Absorber Tube}

The absorber tube is simulated by the conservation of energy rate for finite control volume under unsteady-state conditions. The control volume undergoes convective heat transfer from its inner surface to the heat transfer fluid, connective and radiative heat transfer from its outer surface to the cover tube through annuals medium, and the incoming solar radiation reaches the absorber. The conservation of energy yields to Eq. 18;

$$
\frac{d U_{a}}{d t}=\left(\dot{q}_{\mathrm{sa}}-\dot{\mathrm{q}}_{1}-\dot{\mathrm{q}}_{2}-\dot{\mathrm{q}}_{3}\right) \pi \mathrm{d}_{2} \mathrm{dx}
$$

Where;

$\mathrm{U}_{\mathrm{a}}=\rho_{\mathrm{a}} \mathrm{A}_{\mathrm{a}} \mathrm{C}_{\mathrm{a}} \mathrm{T}_{\mathrm{a}} \mathrm{dx}$

$\dot{\mathrm{q}}_{2}=\mathrm{h}_{2}\left(\mathrm{~T}_{\mathrm{a}}-\mathrm{T}_{\mathrm{c}}\right)$

$\dot{\mathrm{q}}_{3}=\mathrm{h}_{3}\left(\mathrm{~T}_{\mathrm{a}}-\mathrm{T}_{\mathrm{c}}\right)$

Eq. 18 is re-written to be Eq. 21, which represents the time distribution for the temperature of the absorber tube.

$$
\frac{\mathrm{dT}_{\mathrm{a}}}{\mathrm{dt}}=\frac{\pi \mathrm{d}_{2}}{\rho_{\mathrm{a}} \mathrm{A}_{\mathrm{a}} \mathrm{C}_{\mathrm{a}}}\left(\dot{\mathrm{q}}_{\mathrm{sa}}-\dot{\mathrm{q}}_{1}-\dot{\mathrm{q}}_{2}-\dot{\mathrm{q}}_{3}\right)
$$

Solution of Eq. 21 requires the values of convective and radiative heat transfer coefficients between the outer surface of the absorber tube to the cover tube through annuals medium. The convective heat transfer coefficient is correlated based on the type of annuals filling conditions, for the vacuum annuals where $P<100$ $\mathrm{mmHg}$ the free molecule convection approach [11] and correlated as [17], with the molecular properties are listed in Table 1 [13]: 


$$
\begin{aligned}
& \overline{\mathrm{T}_{\mathrm{g}}}=\frac{\mathrm{T}_{\mathrm{a}}+\mathrm{T}_{\mathrm{c}}}{2} \\
& \mathrm{Z}_{\mathrm{mol}}=\frac{2.331 \times 10^{-20} \overline{\mathrm{T}}_{\mathrm{g}}}{\mathrm{Pd}_{\mathrm{mol}}^{2}} \\
& \mathrm{IC}_{\mathrm{mol}}=\frac{(2-\mathrm{A})(9 \gamma-5)}{2 \mathrm{~A}(\gamma+1)} \\
& \mathrm{h}_{2}=\frac{\lambda_{\mathrm{mol}}}{2 \ln \left(\frac{\mathrm{d}_{3}}{\mathrm{~d}_{2}}\right)}+\mathrm{IC}_{\mathrm{mol}} \mathrm{Z}_{\mathrm{mol}}\left(\frac{\mathrm{d}_{2}}{\mathrm{~d}_{3}}+1\right)
\end{aligned}
$$

Table 1: Properties of Molecules for Different Medium

\begin{tabular}{|l|c|c|c|c|c|}
\hline Gas & $\lambda_{\text {mol }}$ & $\mathrm{IC}_{\text {mol }}$ & $\mathrm{Z}_{\text {mol }}$ & $\gamma$ & $\mathrm{d}_{\text {mol }}$ \\
\hline & $\mathrm{W} / \mathrm{m} . \mathrm{K}$ & & $\mathrm{cm}$ & & $\mathrm{cm}$ \\
\hline Air & 0.02551 & 1.571 & 88.67 & 1.39 & $3.53 \times 10^{-8}$ \\
\hline Hydrogen & 0.1769 & 1.581 & 191.8 & 1.398 & $2.4 \times 10^{-8}$ \\
\hline Aragon & 0.01777 & 1.886 & 76.51 & 1.677 & $3.8 \times 10^{-8}$ \\
\hline
\end{tabular}

While for the natural convection with $P>100 \mathrm{mmHg}$ the free convection approach [11] and the heat transfer coefficient is correlated [3]:

$$
\begin{aligned}
& \mathrm{T}_{\mathrm{g}}=\frac{\mathrm{T}_{\mathrm{a}}+\mathrm{T}_{\mathrm{c}}}{2} \\
& \beta_{\mathrm{g}}=\frac{1}{\mathrm{~T}_{\mathrm{g}}}
\end{aligned}
$$

$\mathrm{d}_{\mathrm{g}}=\frac{2\left[\ln \left(\frac{\mathrm{d}_{3}}{\mathrm{~d}_{2}}\right)\right]^{\frac{4}{3}}}{\left[\left(\frac{\mathrm{d}_{3}}{2}\right)^{\frac{-3}{5}}+\left(\frac{\mathrm{d}_{3}}{2}\right)^{\frac{-3}{5}}\right]^{\frac{5}{3}}}$

$\operatorname{Ra}_{\mathrm{g}}=\frac{\mathrm{g} \beta_{\mathrm{g}}\left(\mathrm{T}_{\mathrm{a}}-\mathrm{T}_{\mathrm{c}}\right) \mathrm{d}_{\mathrm{g}}{ }^{3}}{v_{\mathrm{g}} \alpha_{\mathrm{g}}}$

$\mathrm{h}_{2}=2.425 \lambda_{\mathrm{g}}\left(\frac{\operatorname{Pr}_{\mathrm{g}} \mathrm{Ra}_{\mathrm{g}}}{0.861+\operatorname{Pr}_{\mathrm{g}}}\right)^{\frac{1}{4}}\left(1+\left(\frac{\mathrm{d}_{3}}{\mathrm{~d}_{4}}\right)^{\frac{3}{5}}\right)^{\frac{-5}{4}}$

The radiative heat transfer coefficient is correlated as [6], while the view factor between the absorber and cover tubes is assumed equal to 1 .

$$
\mathrm{h}_{3}=\frac{\sigma\left(\mathrm{T}_{\mathrm{a}}{ }^{2}+\mathrm{T}_{\mathrm{c}}{ }^{2}\right)\left(\mathrm{T}_{\mathrm{a}}+\mathrm{T}_{\mathrm{c}}\right)}{\frac{1-\varepsilon_{\mathrm{c}}}{\varepsilon_{\mathrm{a}}}+\frac{1}{\mathrm{~F}_{\mathrm{ac}}}+\frac{\left(1-\varepsilon_{\mathrm{c}}\right) \mathrm{d}_{2}}{\varepsilon_{\mathrm{c}} \mathrm{d}_{3}}}
$$

\subsection{Simulation of Cover Tube}

The cover tube is simulated by the conservation of energy rate for finite control volume under unsteady-state conditions. The control volume undergoes convective and radiative heat transfer to its inner surface from the absorber tube, connective and radiative heat transfer from its outer surface to the ambient and 
sky respectively, and the incoming solar radiation reaches the cover tube. The conservation of energy yields to Eq. 32;

$$
\frac{d U_{c}}{d t}=\left(\dot{q}_{s c}-\dot{q}_{4}-\dot{q}_{5}\right) \pi d_{4} d x+\left(\dot{q}_{2}+\dot{q}_{3}\right) \pi d_{2} d x
$$

Where;

$$
\begin{aligned}
& \mathrm{U}_{\mathrm{c}}=\rho_{\mathrm{c}} \dot{\mathrm{A}}_{\mathrm{c} 1} \mathrm{~T}_{\mathrm{c}} \mathrm{dx} \\
& \dot{\mathrm{q}}_{4}=\mathrm{h}_{4}\left(\mathrm{~T}_{\mathrm{c}}-\mathrm{T}_{\infty}\right) \\
& \dot{\mathrm{q}}_{5}=\mathrm{h}_{5}\left(\mathrm{~T}_{\mathrm{c}}-\mathrm{T}_{\mathrm{sky}}\right)
\end{aligned}
$$

Eq. 32 is re-written to Eq. 36, which represents the time distribution for the temperature of the cover tube.

$$
\frac{\mathrm{dT}_{\mathrm{c}}}{\mathrm{dt}}=\frac{\pi \mathrm{d}_{4}}{\rho_{\mathrm{c}} \mathrm{A}_{\mathrm{c}} \mathrm{C}_{\mathrm{c}}}\left(\dot{\mathrm{q}}_{\mathrm{sc}}-\dot{\mathrm{q}}_{4}-\dot{\mathrm{q}}_{5}\right)+\frac{\pi \mathrm{d}_{2}}{\rho_{\mathrm{c}} \mathrm{A}_{\mathrm{c}} \mathrm{C}_{\mathrm{c}}}\left(\dot{\mathrm{q}}_{2}+\dot{\mathrm{q}}_{3}\right)
$$

Solution of Eq. 36 requires the values of convective and radiative heat transfer coefficients between the outer surface of the cover tube to the ambient and sky respectively. The convective heat transfer coefficient is correlated [10]:

$$
\begin{aligned}
& \operatorname{Re}_{\infty}=\frac{\rho_{\infty} \mathrm{v}_{\infty} \mathrm{d}_{4}}{\mu_{\infty}} \\
& 0.4<\operatorname{Re}_{\infty} \leq 40 \quad \mathrm{~h}_{4}=0.989 \operatorname{Re}_{\infty}{ }^{0.33} \operatorname{Pr}_{\infty} \frac{1}{3} \frac{\lambda_{\infty}}{\mathrm{d}_{4}} \\
& 40<\operatorname{Re}_{\infty} \leq 4000 \mathrm{~h}_{4}=0.683 \operatorname{Re}_{\infty}^{0.486} \operatorname{Pr}_{\infty} \frac{1}{3} \frac{\lambda_{\infty}}{\mathrm{d}_{4}} \\
& 4000<\operatorname{Re}_{\infty} \leq 40000 \mathrm{~h}_{4}=0.193 \operatorname{Re}_{\infty}^{0.618} \operatorname{Pr}_{\infty} \frac{1}{3} \frac{\lambda_{\infty}}{\mathrm{d}_{4}} \\
& 40000<\operatorname{Re}_{\infty} \leq 400000 \mathrm{~h}_{4}=0.0266 \operatorname{Re}_{\infty}{ }^{0.805} \operatorname{Pr}_{\infty} \frac{1}{3} \frac{\lambda_{\infty}}{\mathrm{d}_{4}}
\end{aligned}
$$

The value of heat transfer coefficient obtained from previous correlations is compared with the corresponding value obtained for free convection [4] and the maximum value is considered.

$$
\begin{aligned}
\overline{T_{\infty}} & =\frac{T_{\infty}+T_{c}}{2} \\
\beta_{\infty}= & \frac{1}{\overline{T_{\infty}}} \\
\operatorname{Ra}_{\infty}= & \frac{g \beta_{\infty}\left(T_{c}-T_{\infty}\right) d_{4}{ }^{3}}{v_{\infty} \alpha_{\infty}} \\
\mathbf{h}_{4}= & \left.0.6+0.387\left(\frac{R_{\infty}}{1+\left(\frac{0.559}{P_{\infty}}\right)^{\frac{9}{16}}}\right)^{\frac{1}{6}}\right]^{\frac{\lambda_{\infty}}{d_{4}}}
\end{aligned}
$$

The radiative heat transfer coefficient is correlated as:

$$
\mathrm{T}_{\text {sky }}=0.0552 \mathrm{~T}_{\infty}^{1.5}
$$


$\mathrm{h}_{5}=\varepsilon_{\mathrm{c}} \sigma\left(\mathrm{T}_{\mathrm{sky}}^{2}+\mathrm{T}_{\mathrm{c}}^{2}\right)\left(\mathrm{T}_{\text {sky }}+\mathrm{T}_{\mathrm{c}}\right)$

\subsection{Numerical Formulation}

Dividing the parabolic trough collector into a number $(\mathrm{N})$ of control volumes, each control volume contains the heat transfer fluid, absorber tube, and cover tube, then the main three Eqs. 12, 21, and 36 are numerically formulated explicitly respectively as:

$$
\begin{aligned}
& \mathrm{T}_{\mathrm{f}(\mathrm{t}+\Delta \mathrm{t}, \mathrm{I}+1)}=\mathrm{T}_{\mathrm{f}(\mathrm{t}, \mathrm{I}+\mathrm{l})}+\frac{\Delta \mathrm{t}}{\rho_{\mathrm{f}} \mathrm{A}_{1} \mathrm{C}_{\mathrm{f}}}\left(\dot{\mathrm{q}}_{1} \pi \mathrm{d}_{1}-\dot{\mathrm{m}}_{\mathrm{f}} \mathrm{C}_{\mathrm{f}} \frac{\left.\mathrm{T}_{\mathrm{f}(\mathrm{t}, \mathrm{I}+\mathrm{l})}-\mathrm{T}_{\mathrm{f}(\mathrm{t}, \mathrm{I})}\right)}{\mathrm{dx}}\right) \\
& \mathrm{T}_{\mathrm{a}(\mathrm{t}+\Delta \mathrm{t}, \mathrm{I}+1)}=\mathrm{T}_{\mathrm{a}(\mathrm{t}, \mathrm{I}+1)}+\frac{\pi \mathrm{d}_{2} \Delta \mathrm{t}}{\rho_{\mathrm{a}} \mathrm{A}_{\mathrm{a}} \mathrm{C}_{\mathrm{a}}}\left(\dot{\mathrm{q}}_{\mathrm{sa}}-\dot{\mathrm{q}}_{1}-\dot{\mathrm{q}}_{2}-\dot{\mathrm{q}}_{3}\right) \\
& \mathrm{T}_{\mathrm{c}(\mathrm{t}+\Delta t, \mathrm{I}+1)}=\mathrm{T}_{\mathrm{c}(\mathrm{t}, \mathrm{I}+1)}+\frac{\pi \mathrm{d}_{4} \Delta \mathrm{t}}{\rho_{\mathrm{c}} \mathrm{A}_{\mathrm{c}} \mathrm{C}_{\mathrm{c}}}\left(\dot{\mathrm{q}_{\mathrm{sc}}}-\dot{\mathrm{q}}_{4}-\dot{\mathrm{q}}_{5}\right)+\frac{\pi \mathrm{d}_{2} \Delta \mathrm{t}}{\rho_{\mathrm{c}} \mathrm{A}_{\mathrm{c}} \mathrm{C}_{\mathrm{c}}}\left(\dot{\mathrm{q}}_{2}+\dot{\mathrm{q}}_{3}\right)
\end{aligned}
$$

While, the initial conditions are defined for $t=0$ and the boundary conditions are defined for $I=1$, The heat transfer terms at each time are calculated as:

$$
\dot{\mathrm{Q}}_{1}=\sum_{\mathrm{I}=1}^{\mathrm{I}=\mathrm{N}} \mathrm{q}_{1} \quad \dot{\mathrm{Q}}_{2}=\sum_{\mathrm{I}=1}^{\mathrm{I}=\mathrm{N}} \mathrm{q}_{2} \quad \dot{\mathrm{Q}}_{3}=\sum_{\mathrm{I}=1}^{\mathrm{I}=\mathrm{N}} \mathrm{q}_{3} \quad \dot{\mathrm{Q}}_{4}=\sum_{\mathrm{I}=1}^{\mathrm{I}=\mathrm{N}} \mathrm{q}_{4} \quad \dot{\mathrm{Q}}_{5}=\sum_{\mathrm{I}=1}^{\mathrm{I}=\mathrm{N}} \mathrm{q}_{5}
$$

Computer software is constructed in VISUAL FORTRAN environment, where the parabolic trough collector is simulated and the software is flexible to deduce the performance of parabolic trough collector with any design, operating, and weather conditions.

\section{ANALYSIS OF THERMAL BEHAVIOR OF PARABOLIC TROUGH SOLAR COLLECTOR}

The main input data for the proposed simulator are categorized to the following conditions:

\section{A. Design Conditions;}

The parabolic trough collector that is chosen in the study has the design conditions in Table 2 [5], the optical properties in Table 3 [16] with air in the annuals area.

Table 2: PTC Design Conditions

\begin{tabular}{|l|l|l|}
\hline $\mathrm{L}$ & $=7.8$ & $\mathrm{~m}$ \\
\hline $\mathrm{W}$ & $=5$ & $\mathrm{~m}^{2}$ \\
\hline $\mathrm{C}_{2}$ & $=500$ & $\mathrm{~J} / \mathrm{kg} \cdot \mathrm{K}$ \\
\hline$\rho_{\mathrm{z}}$ & $=8020$ & $\mathrm{~kg} / \mathrm{m}^{3}$ \\
\hline $\mathrm{C}_{\mathrm{c}}$ & $=1090$ & $\mathrm{~J} / \mathrm{kg} \cdot \mathrm{K}$ \\
\hline$\rho_{c}$ & $=2230$ & $\mathrm{~kg} / \mathrm{m}^{3}$ \\
\hline $\mathrm{d}_{1}$ & $=0.066$ & $\mathrm{~m}$ \\
\hline $\mathrm{d}_{2}$ & $=0.07$ & $\mathrm{~m}$ \\
\hline $\mathrm{d}_{3}$ & $=0.109$ & $\mathrm{~m}$ \\
\hline $\mathrm{d}_{4}$ & $=0.115$ & $\mathrm{~m}$ \\
\hline $\mathrm{F}_{\mathrm{uc}}$ & $=1$ & \\
\hline $\mathrm{K}$ & $=1$ & \\
\hline
\end{tabular}

Table 3: PTC Optical Properties

\begin{tabular}{|l|l|}
\hline$\rho_{c m}$ & $=0.935$ \\
\hline$\alpha_{2}$ & $=0.906$ \\
\hline$\alpha_{c}$ & $=0.02$ \\
\hline$\tau_{c}$ & $=0.95$ \\
\hline$\varepsilon_{c}$ & $=0.86$ \\
\hline$\varepsilon_{2}$ & $=0.14$ \\
\hline$\varepsilon_{1}$ & $=0.974$ \\
\hline$\varepsilon_{2}$ & $=0.994$ \\
\hline$\varepsilon_{3}$ & $=0.98$ \\
\hline$\varepsilon_{4}$ & $=0.88: 0.93 / P_{\mathrm{cm}}$ \\
\hline$\varepsilon_{5}$ & $=0.5\left(\varepsilon_{4}+1\right)$ \\
\hline$\varepsilon_{6}$ & $=0.96$ \\
\hline
\end{tabular}

\section{B. Operating Conditions;}

The parabolic trough collector operates with Therminol 66; Therminol 66 is a high performance stable synthetic heat transfer fluid offering extended life and very low top-up rates resulting in reduced running costs 
and minimal downtime for operations at temperatures up to $345{ }^{\circ} \mathrm{C}$. The physical, chemical, and thermal properties of Therminol 66 are in Table 4.

Table 4: Typical Physical, Chemical and Thermal Properties of Therminol 66

\begin{tabular}{lll}
\hline Composition & & Hydrogenated terphenyl \\
\hline Appearance & & Clear pale yellow liquid \\
\hline Max. bulk temperature & & $345^{\circ} \mathrm{C}$ \\
\hline Max. film temperature & DIN $51562-1$ & $375^{\circ} \mathrm{C}$ \\
\hline Kinematic viscosity @ $40^{\circ} \mathrm{C}$ & DIN 51757 & $29.64 \mathrm{~mm}^{2} / \mathrm{s}(\mathrm{cSt})$ \\
\hline Density @ $15^{\circ} \mathrm{C}$ & DIN EN 22719 & $1011 \mathrm{~kg} / \mathrm{m}^{3}$ \\
\hline Flash point (Closed cup) & ISO 2592 & $170^{\circ} \mathrm{C}$ \\
\hline Fire point & DIN 51794 & $216^{\circ} \mathrm{C}$ \\
\hline Autoignition temperature & ISO 3016 & $399^{\circ} \mathrm{C}$ \\
\hline Pour point & & $-32^{\circ} \mathrm{C}$ \\
\hline Boiling point @ 1013 mbar & & $359^{\circ} \mathrm{C}$ \\
\hline Coefficient of thermal expansion & $0.0009 /{ }^{\circ} \mathrm{C}$ \\
\hline Moisture content & DIN $51777-1$ & $<150 \mathrm{ppm}$ \\
\hline Total acidity & DIN $51558-1$ & $<0.02 \mathrm{mg} \mathrm{KOH} / \mathrm{g}$ \\
\hline Chlorine content & DIN $51577-3$ & $<10 \mathrm{ppm}$ \\
\hline Copper corrosion & EN ISO 2160 & $<<1 \mathrm{a}$ \\
\hline Average molecular weight & & 252 \\
\hline
\end{tabular}

The properties of Therminol 66 are correlated as a function of temperature as follows:

$\rho_{\mathrm{f}}=-0.614254 \mathrm{~T}_{\mathrm{f}}-0.000321 \mathrm{~T}_{\mathrm{f}}^{2}+1020.62$

$\mathrm{C}_{\mathrm{f}}=1000.0\left(-0.003313 \mathrm{~T}_{\mathrm{f}}+0.0000008970785 \mathrm{~T}_{\mathrm{f}}^{2}+1.496005\right)$

$\lambda_{\mathrm{f}}=-0.000033 \mathrm{~T}_{\mathrm{f}}-0.00000015 \mathrm{~T}_{\mathrm{f}}^{2}+0.118294$

$v_{f}=10^{-6} e^{\left(\frac{586.375}{T_{\mathrm{f}}+62.5}-2.2809\right)}$

The flow rate of the heat transfer fluid inside the absorber tube is kept constant at $0.001 \mathrm{~kg} / \mathrm{s}$ which is suitable for the studied parabolic trough collector [12].

\section{Weather Conditions;}

The work herein is based on using the parabolic trough with previous design and operating conditions located in Arab Republic of Egypt (A.R.E.) - Cairo - Cairo International Airport district. The weather data are referred to that published in Solar Advisor Model SAM- National Renewable Energy Laboratory "NREL"Version 2012.5.11. The Geography for the location is illustrated in Table 5, while the monthly profile for global horizontal solar radiation, ambient dry bulb temperature, and wind speed are shown in Figures 3, 4, and 5 respectively

Table 5: Geography of Cairo International Air Port - Cairo - Egypt

[Solar Advisor Model- National Renewable Energy Laboratory "NREL"-Version 2012.5.11]

\begin{tabular}{|c|c|c|c|c|c|}
\hline \multicolumn{2}{|c|}{-Location Information- } & \multirow[b]{2}{*}{ Timezone } & \multirow[b]{2}{*}{ GMT 2} & \multirow[b]{2}{*}{ Latitude } & \multirow[b]{2}{*}{$30.13 \mathrm{deg}$} \\
\hline City & Cairo Int Airport & & & & \\
\hline State & Al Qahirah & Elevation & $74 m$ & Longitude & $31.4 \mathrm{deg}$ \\
\hline
\end{tabular}



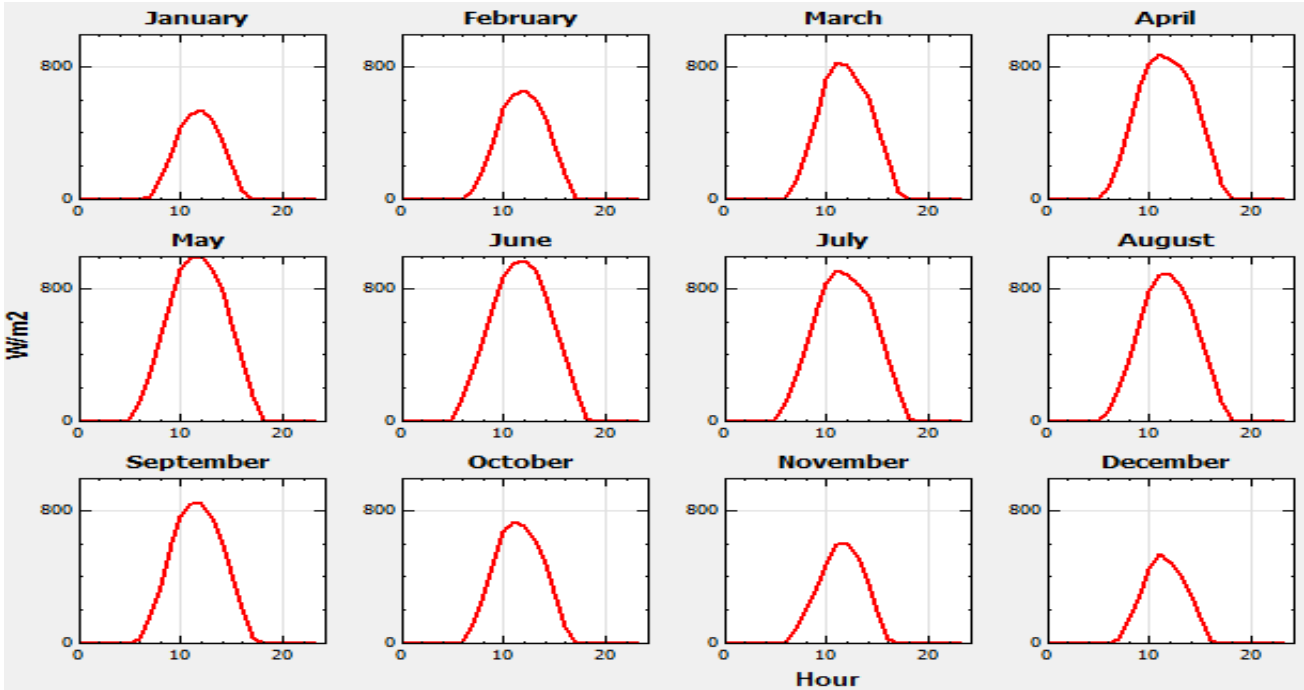

Fig. 3: Monthly Profile for the Global Horizontal Solar Radiation

[Solar Advisor Model- National Renewable Energy Laboratory "NREL"-Version 2012.5.11]
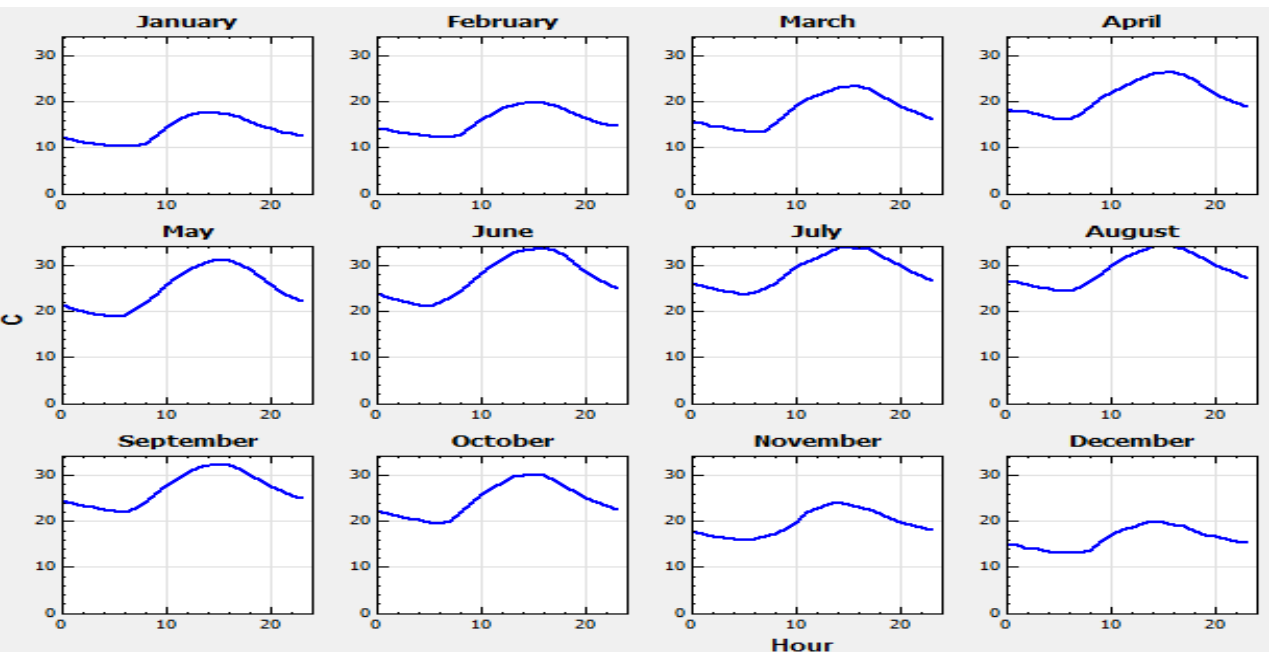

Fig. 4: Monthly Profile for the Ambient Dry Bulb Temperature

[Solar Advisor Model- National Renewable Energy Laboratory "NREL"-Version 2012.5.11]
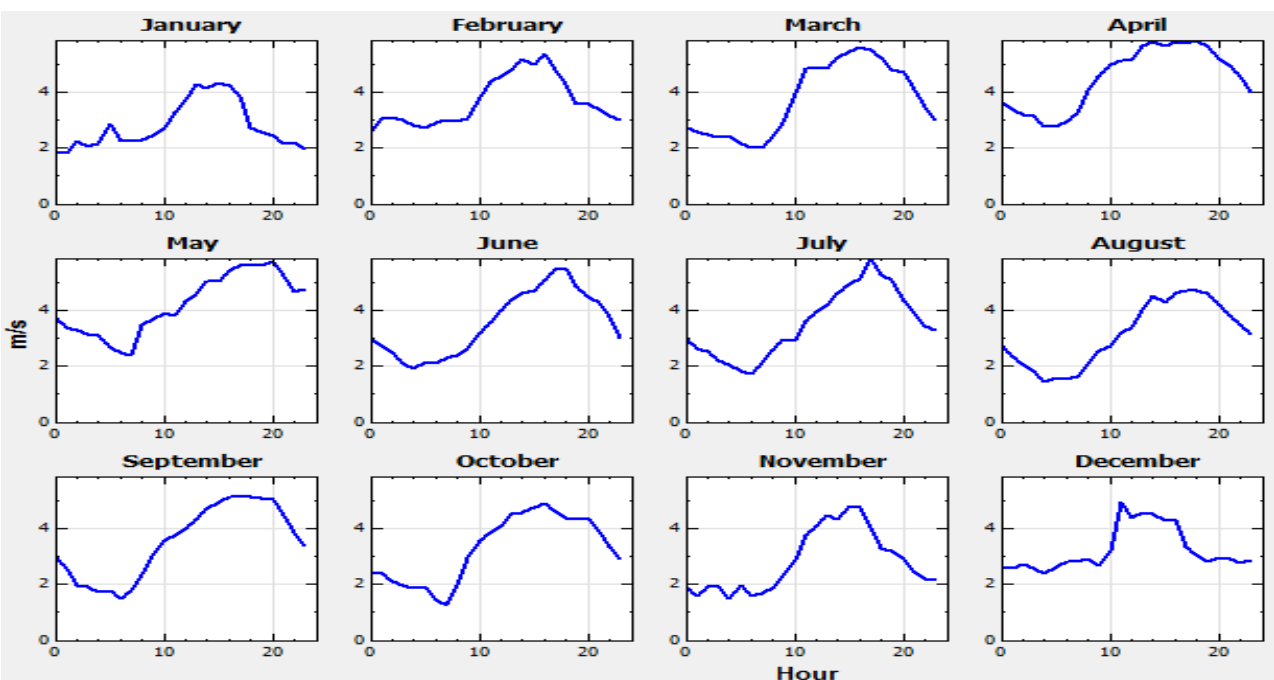

Fig. 5: Monthly Profile for the Wind Speed

[Solar Advisor Model- National Renewable Energy Laboratory "NREL"-Version 2012.5.11] 
As shown in Fig. 3, May has the highest solar radiation over the rest of the months; therefore May is taken as the design month. The sunshine period starts from hour 5 to hour 18, with the maximum global horizontal solar radiation of $1000.0 \mathrm{~W} / \mathrm{m}^{2}$ at hour 12 .

\section{RESULTS AND DISCUSSION}

The parabolic trough solar collector with the design conditions shown in Tables 2, 3 and used to heat the heat transfer fluid that has the properties in Table 4. This parabolic trough solar collector is located in the location described in Table 5, and subjected to the weather conditions as in Figs. 3, 4, and 5 for May. The simulator presented herein run for the parabolic trough solar collector starts from the $\mathrm{t}=5 \mathrm{hr}$ to $18 \mathrm{hr}$ which covers the sunshine period.

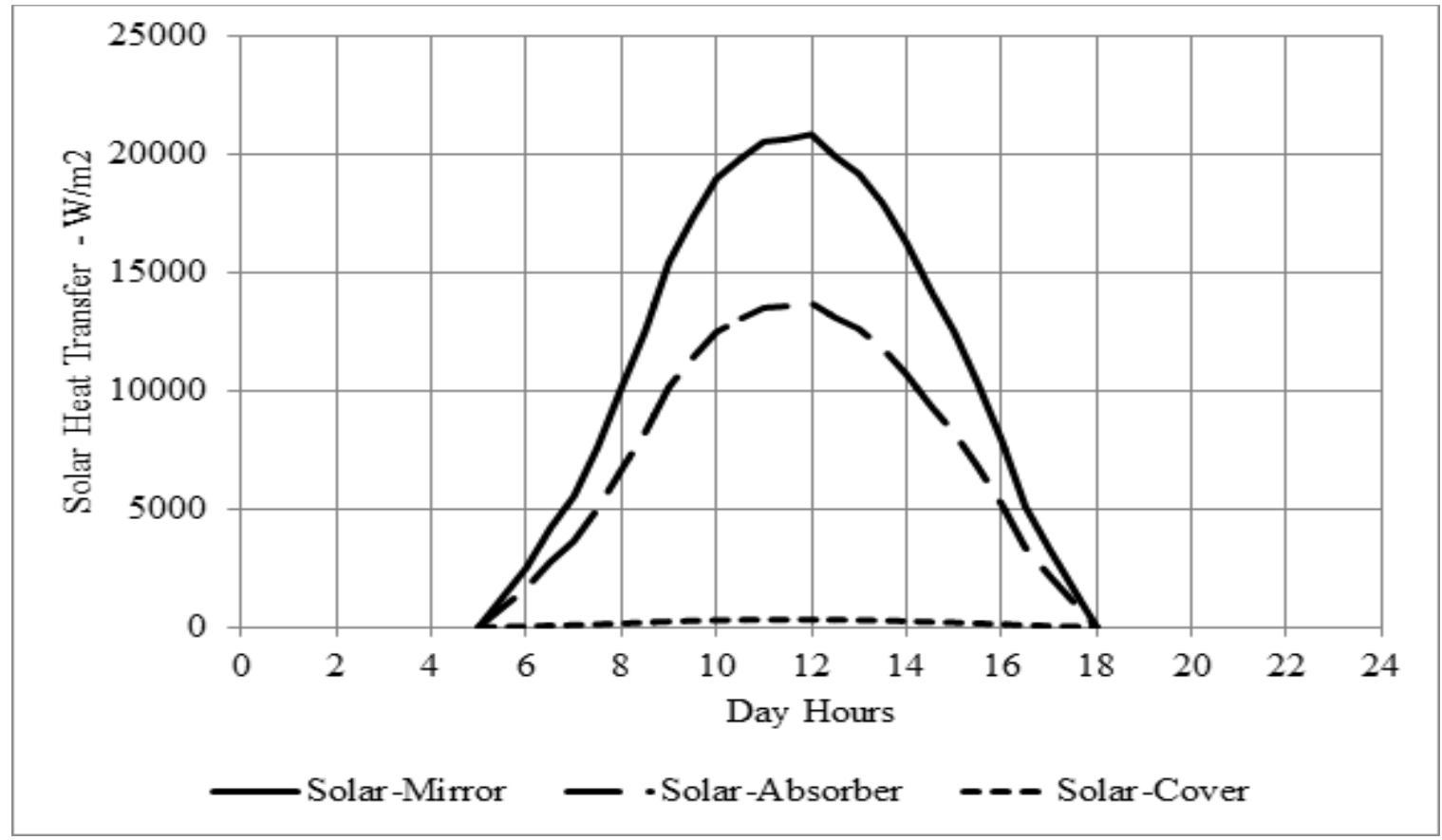

Fig. 6: Hourly Distribution of Various Solar Radiations during Sunshine Period

Fig. 6 illustrates the hourly distribution of the reflected solar radiation from the mirror surface (SolarMirror) during the sunshine period. The values of the reflected solar radiation from the mirror surface are much higher than the global horizontal solar radiation as a result of the concentration ratio of the parabolic trough geometry. For the studied case; the concentration ratio is 22.0 with smaller effect of the mirror surface reflectivity, the maximum reflected solar radiation from the mirror surface is $20849.0 \mathrm{~W} / \mathrm{m}^{2}$ and achieved at hour 12 while at this time the maximum global horizontal solar radiation is $1000.0 \mathrm{~W} / \mathrm{m}^{2}$.

Also, Fig. 6 illustrates the hourly distribution of the solar radiation absorbed by the absorber tube (Solar-Absorber) during the sunshine period, which is considered the motive force to heat the flowing heat transfer fluid. The value of this absorbed heat reaches its maximum value of $13715.04 \mathrm{~W} / \mathrm{m}^{2}$ at hour 12 . Generally; the ratio between the solar absorbed by the absorber tube and the reflected solar radiation from the mirror surface is in the range of $65.8 \%$, this ratio is dependent only on the optical properties of the parabolic trough collector.

Fig. 6 illustrates the hourly distribution of the solar radiation absorbed by the cover tube (Solar-Cover) during the sunshine period. The value of this absorbed heat reaches its maximum value of $318.7 \mathrm{~W} / \mathrm{m}^{2}$ at hour 12. The optical properties of the parabolic trough collector such as the absorptivity of the cover material, govern the ratio between the solar absorbed by the cover tube and the reflected solar radiation from the mirror surface in the range of $1.53 \%$. One can deduce that; $32.67 \%$ from the reflected solar radiation from the mirror surface is dissipated as heat loss to the surrounding environment in different forms of heat loss. The forms of the heat losses depend on the weather conditions such as the ambient temperature, and the wind speed. 


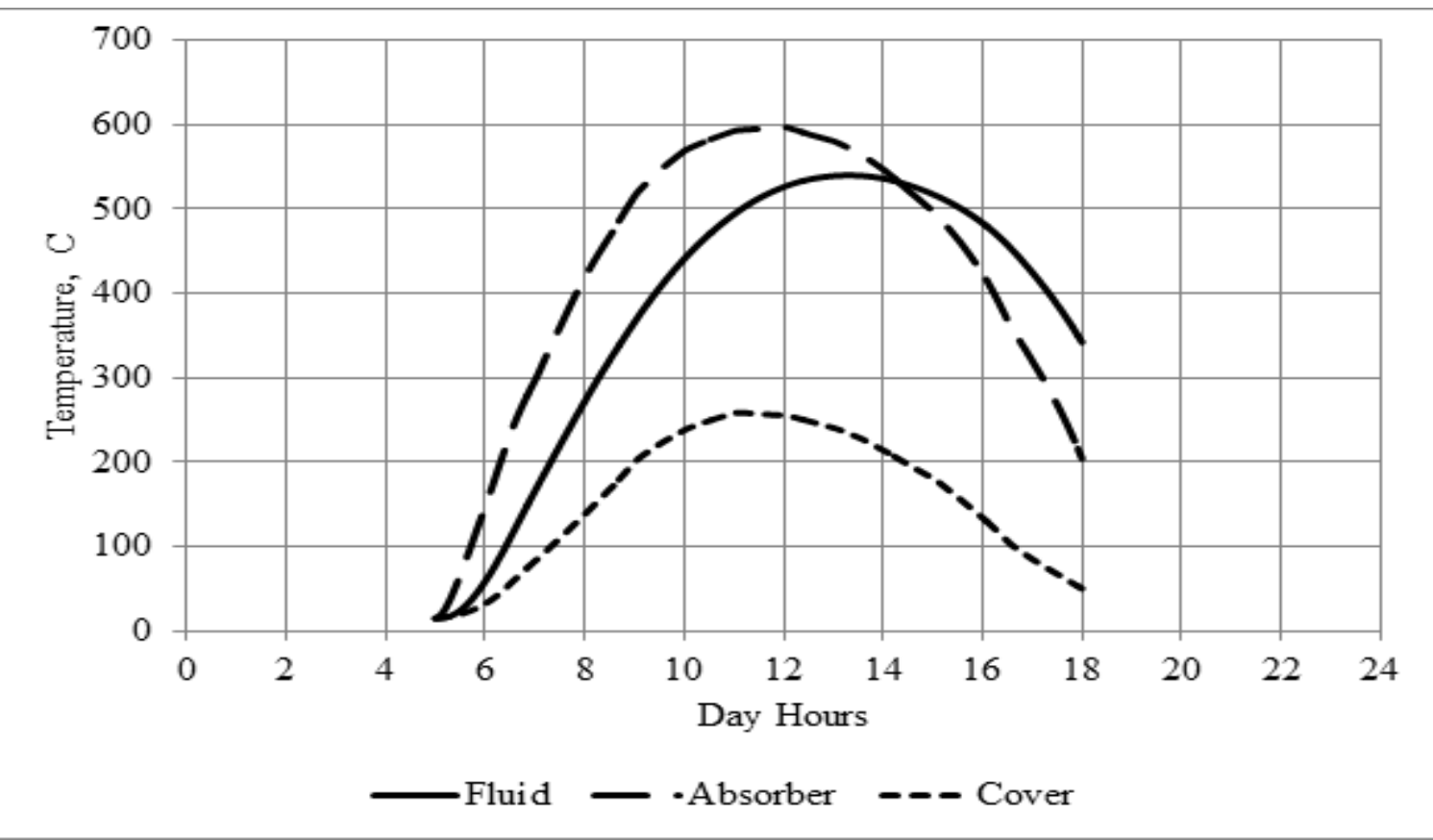

Fig. 7: Hourly Distribution of the Temperature of Heat Transfer Fluid, Absorber Tube, and Cover Tube at Outflow Location during Sunshine Period - For Heat Transfer Fluid Flow of $0.001 \mathrm{~kg} / \mathrm{s}$

Fig. 7 illustrates the hourly distribution of the temperature for the heat transfer fluid, absorber tube, and cover tube at the outflow location during the sunshine period, for flow of $0.001 \mathrm{~kg} / \mathrm{s}$ of heat transfer fluid. Starting from the initial conditions of $15{ }^{\circ} \mathrm{C}$; the temperature of the absorber tube increases to $597.0{ }^{\circ} \mathrm{C}$ at hour 12 , while for the heat transfer fluid increases to $539.0^{\circ} \mathrm{C}$ at hour 13.30 , and for the cover tube increases to 258.6 ${ }^{\circ} \mathrm{C}$ at hour 11.097.

At hour 14.317 and beyond, the temperature of the absorber tube is lower than the temperature of the heat transfer fluid, which indicates that; the heat transfer fluid heats the absorber tube till the sunset time. Since the temperature of the heat transfer fluid is the motive force in the energy storage and transmission of heat for the desired application, then the temperature profile will be very required.

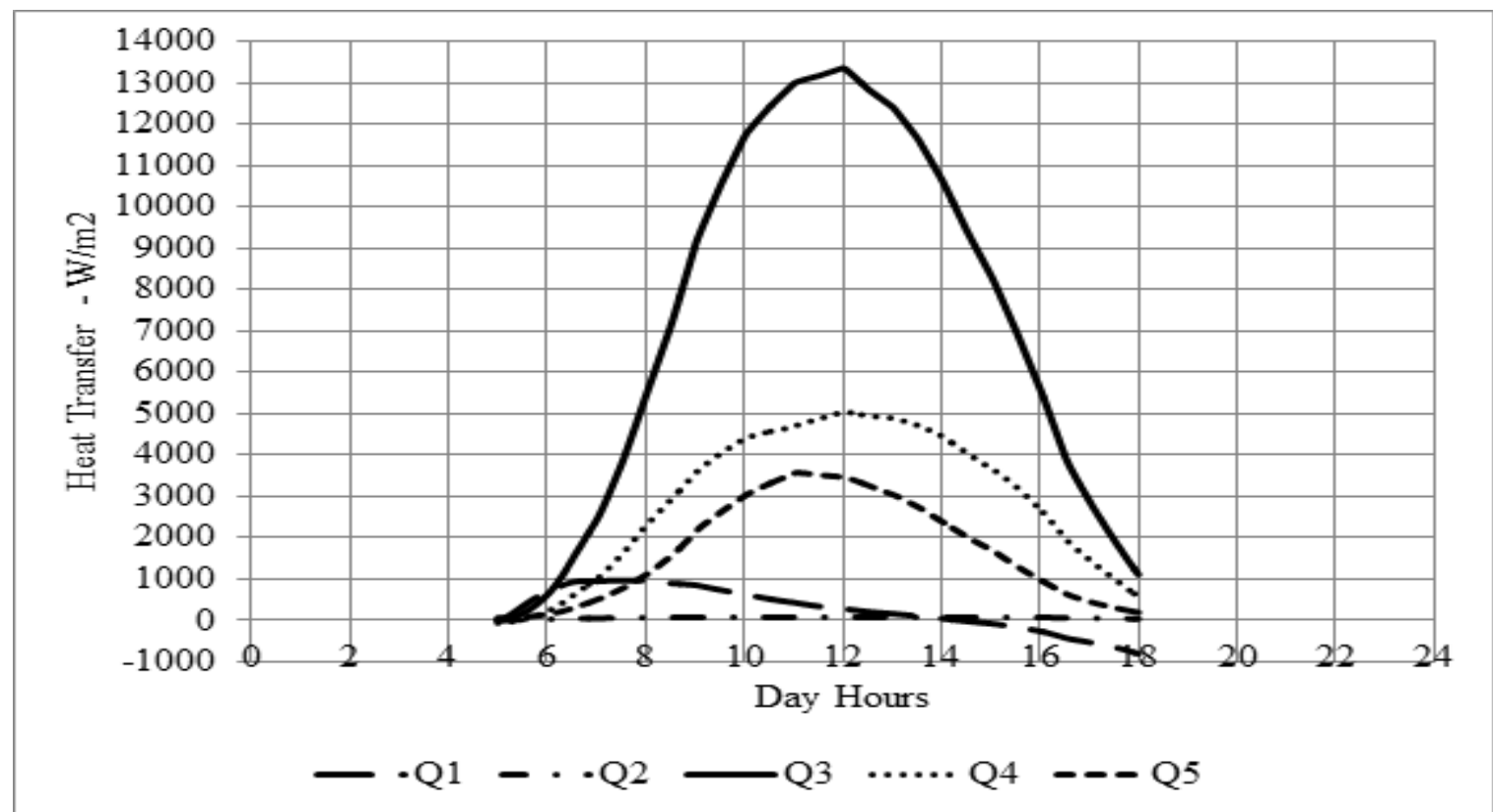

Fig. 8: Hourly Distribution of the Various Total Heat Transfers during Sunshine Period - For Heat Transfer Fluid Flow of $0.001 \mathrm{~kg} / \mathrm{s}$ 
Fig. 8 illustrates the hourly distribution of various total heat transfers during the sunshine period, for flow of $0.001 \mathrm{~kg} / \mathrm{s}$ of heat transfer fluid. Firstly; it is noticed that; after hour 14.317 and beyond the value of heat transfer from the absorber tube to the heat transfer fluid reverses its direction as a result of the illustrated in Fig. 7. The maximum heat transfer is that in the form of radiation from the absorber tube to the cover tube, while, the minimum is that in the form of convection from the absorber tube to the cover tube through the annuals air.

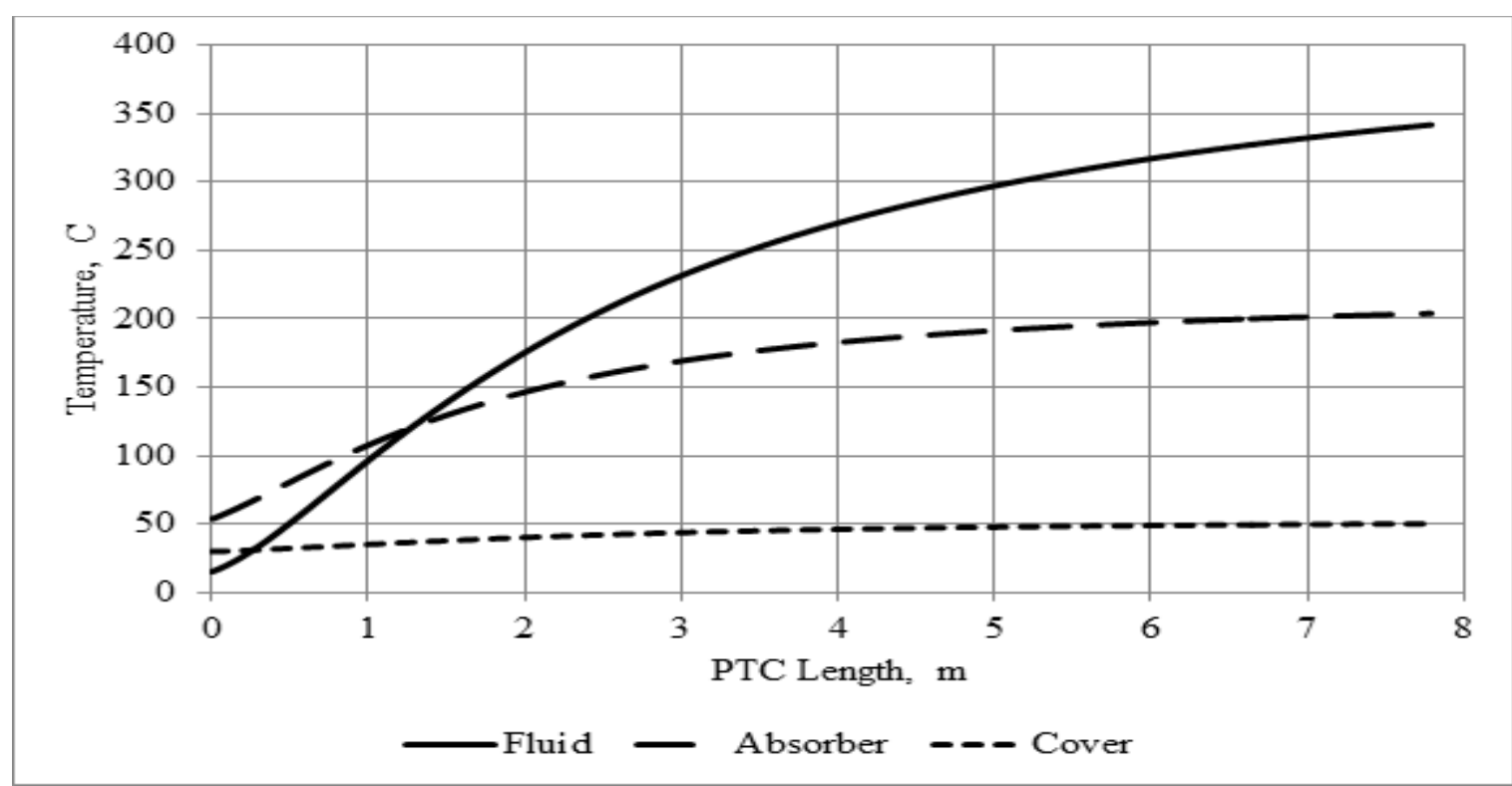

Fig. 9: Distribution of the Temperature for Heat Transfer Fluid, Absorber Tube, and Cover Tube along the PTC Length at Sunshine End Time for Heat Transfer Fluid Flow of $0.001 \mathrm{~kg} / \mathrm{s}$

Fig. 9 illustrates the distribution of the temperature for heat transfer fluid, absorber tube, and cover tube along the PTC length at the sunshine end time for flow of $0.001 \mathrm{~kg} / \mathrm{s}$ of heat transfer fluid. Referring to Figure 6 at hour 18 , the temperatures are $342.0^{\circ} \mathrm{C}$ for heat transfer fluid, $204.0{ }^{\circ} \mathrm{C}$ for the absorber tube, and $50.2{ }^{\circ} \mathrm{C}$ for the cover tube.

\section{CONCLUSIONS AND RECOMMENDATIONS FOR FUTURE WORK}

For the studied case, it is concluded that;

1. The maximum reflected solar radiation from the mirror surface is $20849.0 \mathrm{~W} / \mathrm{m}^{2}$ at hour 12 .

2. The ratio between the solar absorbed by the absorber tube and the reflected solar radiation from the mirror surface is $65.8 \%$, this ratio depends only on the optical properties of the parabolic trough collector.

3. The ratio between the solar absorbed by the cover tube and the reflected solar radiation from the mirror surface is $1.53 \%$.

4. $32.67 \%$ from the reflected solar radiation from the mirror surface is dissipated as heat loss to the surrounding environment in different forms of heat loss.

5. For flow of $0.001 \mathrm{~kg} / \mathrm{s}$ of heat transfer fluid;

a) The temperature of the absorber tube increases to $597.0{ }^{\circ} \mathrm{C}$ at hour 12 , while the heat transfer fluid increases to $539.0^{\circ} \mathrm{C}$ at hour 13.30 and the cover tube increases to $258.6{ }^{\circ} \mathrm{C}$ at hour 11.097 .

b) After hour 14.317 and beyond the heat transfer from the absorber tube to the heat transfer fluid reverses its direction.

c) At the sunshine end, the temperatures are $342.0{ }^{\circ} \mathrm{C}$ for heat transfer fluid, $204.0^{\circ} \mathrm{C}$ for the absorber tube, and $50.2^{\circ} \mathrm{C}$ for the cover tube at the exit section.

These conclusions are considered the input parameters to design the thermal storage system and the process response. Also, the present model will be applied on the first module of parabolic trough collector that is constructed completely in Solar Lab. - Department of Mechanical Power Engineering - Faculty of Engineering - Ain Shams University - Cairo Egypt. 


\section{REFERENCES}

[1]. A. Giostri, M. Binotti, P. Sliva, E. Macchi, G. Manzolini, (2011). Comparison of Two Linear Collectors in Solar Thermal Plant; Parabolic Trough VS Fresnel. Proceedings of the ASME $20115^{\text {th }}$ International Conference on Energy Sustainability, ES2011, August 7-10, Washington, DC. USA.

[2]. Arpakon Wattana, Wattanapong, Wannee Ekasilp, Ammata Tusnapucki, (2011). Velocity and Temperature Distribution of Flowing Water in a Solar Parabolic Trough Receiver. International Journal of Renewable Energy, Vol. 6, No. 1.

[3]. Bejan A., (1995). Convection Heat Transfer. Second Edition. New York, NY: John Wiley \& Sons.

[4]. Churchill S. W., Chu H. H. S., (1975). Correlating equations for laminar and turbulent free convection from horizontal cylinder. International Journal of Heat and Mass Transfer 18 (9) pp. 1049-1053.

[5]. Dudley, V. E., Kolb, G. J., Mahoney, A. R., (1994). Test Results: SEGS LS-2 Solar Collector. SAND941884. Albuquerque, NM: SANDIA National Laboratories.

[6]. Duffie J. A., Beckman W. A., (1991). Solar Engineering of Thermal Processes. Second Edition, Wiley Interscience, New York, pp. 358-361.

[7]. Garcia-Valladares O., Velazquez N., (2009). Numerical Simulation of Parabolic Trough Solar Collector: Improvement Using Counter Flow Concentric Circular Heat Exchangers. International Journal of Heat and Mass Transfer, (52) pp. 597-609.

[8]. Gnielinski V., (1976). New Equations for Heat and Mass Transfer in Turbulent Pipe and Channel Flow. International Chemical Engineering (16:2) pp. 359-363.

[9]. Incropera F., DeWitt D., (1990). Fundamentals of Heat Transfer. Sixth Edition.

[10]. Karlekar B. V., Desmond R. M., (1977). Engineering Heat Transfer. West Publishing Co.

[11]. KJC Operating Company, (1993). Final Report on HCE Heat Transfer Analysis Code. SANDIA Contract No. AB-0227. Albuquerque, NM: Sandia National Laboratories.

[12]. M. Ouagued, A. Khellaf, (2012). Simulation of the Temperature and Heat Gain by Solar Parabolic Trough Collector in Algeria. World Academy of Science, Engineering and Technology 67

[13]. Marshal, N., transl. (1976). Gas Encyclopedia. New York, NY: Elsevier.

[14]. Mathew Roesle, Volkan Coskun, Aldo Stenifeld, (2011). Numerical Analysis of Heat Loss from a Parabolic Trough Absorber Tube with Active Vacuum System. Proceedings of the ASME $20115^{\text {th }}$ International Conference on Energy Sustainability, ES2011, August 7-10, Washington, DC. USA.

[15]. Ming Qu, David H. Archer, Sophie V. Masson, (2006). A Linear Parabolic Trough Solar Collector Performance Model. Renewable Energy Resources and a Greener Future Vol. VIII-3-3, Shenzhen, China.

[16]. Price, H., (2001). Concentrated Solar Power Use in Africa. NREL/TP. Golden, CO: National Renewable Energy Laboratory.

[17]. Ratzel, A., Hickox, C., Gartling, D., (1979). Techniques for Reducing Thermal Conduction and Natural Convection Heat Losses in Annular Receiver Geometries. Journal of Heat Transfer (101:1); pp. 108-113. 